\title{
The role of corporate social responsibilities in tourism and hospitality: The case of Vietnam
}

\author{
Thi Thu Hoai Nguyen ${ }^{a}$, Thi Thuy Hang Phamb, Trong Thuy Than ${ }^{c}$, Thi Kim Lien Tran ${ }^{d^{*}}$ and Thi \\ Huong Lan Nguyen ${ }^{a}$
}

${ }^{a} V N U$ University of Economics and Business, Vietnam

${ }^{b}$ Faculty of Economics, Vinh University, Vietnam

${ }^{c}$ DANUVI SERVICES TOURIST CO.LTD, Vietnam

${ }^{d}$ University of Economics - Technology for Industries, Vietnam

\section{CHRON I C L E ABSTRACT}

Article history:

Received: October 16, 2019

Received in revised format:

January 302020

Accepted: February 2, 2020

Available online:

February 3, 2020

Keywords:

Corporate social responsibility

Financial performance

Tourism and hospitality in Vi-

etnam

\begin{abstract}
The main objective of this study was to assess the role of corporate social responsibility on tourism and hospitality in Vietnam. To accomplish this, we conducted a field survey and analysis on 886 tourism and hospitality in Vietnam over a 6-month period. The results show that corporate social responsibility helped businesses improve corporate reputation, increase customer satisfaction and improve financial performance of Vietnam tourism and hospitality. Customer satisfaction and corporate reputation had a statistically significant positive impact on the financial performance of these businesses. However, corporate reputation and customer satisfaction did not play a full mediate role in the relationship between corporate social responsibility and financial performance. Finally, we examined the moderate role of foreign ownership and size in the relationship between corporate social responsibility and financial performance, showing that both foreign ownership and firm size had a moderate role on the relationship between corporate social responsibility and financial performance. With the more percent of foreign owned, the implementation of corporate social responsibility, the stronger the impact on the financial performance, the less percentage of foreign owned, which means the implementation of corporate social responsibility had positive impact but less intense. The greater size of enterprises, the more corporate social responsibilities and the better financial performance. In contrast to the smaller businesses, the more corporate social responsibility, the worse financial performance. At the same time, we proposed several solutions to improve the corporate social responsibility for tourism and hospitality in Vietnam.
\end{abstract}

(C) 2020 by the authors; licensee Growing Science, Canada

\section{Introduction}

Tourism development has the potential to create jobs and income for many people, both in the process of building necessary infrastructure and in the operation of tourism services. Tourism also contributes to the national budget in general and the locality in particular through tax obligations, thereby helping local governments improve infrastructure and services to serve residents and visitors. However, in many places, the uncontrolled growth and development of tourism has a negative impact on nature, the environment and local communities. These negative impacts may include the occupation of large areas of land for tourism, the distortion of natural habitats, or the encroachment of tourists into vulnerable ecosystems. Negative environmental impacts include infrastructure interference in the natural landscape, high water and energy consumption, water pollution, sudden increase in waste and many adverse impacts, etc. For local communities, tourism can also distort indigenous cultures and social structures of the community, causing social differentiation. According to the 2002 Cape Town Declaration, 
"Responsible tourism" is unanimously understood as tourism activities and processes that directly or indirectly minimize negative economic, social and environmental impacts, bring more economic benefits to local residents and enhance the prosperity of the tourist destination community. Tourism is responsible for solving the problem between development and conservation; is a method of sustainable development with deep humanity, developed for people to ensure a balance between the elements: inside (local residents), outside (tourists) and intermediaries (enterprises). These are also three key components to participate and benefit from when implementing the responsible tourism process. The requirements set forth when businesses develop sustainable tourism are not affecting the environment, avoiding negative impacts on large areas. At the same time, focusing on developing small areas such as villages, communities with little social and cultural influence. The profit will be shared with local people and the community. Responsible tourism and sustainable tourism share a common goal of sustainable development. Therefore, the principles of responsible tourism and sustainable tourism are environmental integrity, equity and social inclusion, economic development and cultural preservation. Sustainable tourism is a new concept for tourism in Vietnam. But at a time when the world economy is in crisis, tourism has been affected by many difficulties and difficulties, so sustainable tourism has become a special concern in the development strategy of Vietnam's tourism industry. The tourism industry understands that the "remorse" in investment, tourism development will pay due to the consequences that it causes. The problem is what to do and how to make our country's tourism industry develop sustainably. Practicing corporate social responsibility in the tourism and hospitality industry is a topic of interest for many researchers as well as actual businesses. Corporate social responsibility not only brings tangible benefits to enterprises but also brings tremendous intangible benefits to help businesses develop sustainably. Especially for tourism and hotel businesses, the specificity of this industry product directly affects tourists' satisfaction and intention to return, so that business practices are ethical and corporate responsibility is of utmost importance. The relationship between corporate social responsibility and financial performance as well as performance has been of interest to many researchers such as Mishra and Saura (2010); Hasan et al. (2018), etc. However, these studies are mainly in the context of developed countries and research in the material manufacturing industry, the service sector is very few, especially in the tourism and hotel industry. To further contribute to the context of the study on the relationship between corporate social responsibility and financial performance in the tourism and hospitality industry, we conduct this study. The study gives similar results to Hasan et al. (2018) and Mirsha and Saura (2010)which indicated that implementing CSR could improve financial performance and sustainable development.

The structure of the paper in addition to the introduction includes a research review describing previous studies on related topics and related concepts. The research methodology presents the research sample, research model and research hypotheses. The research results discuss the results obtained. Finally, in the conclusion section we compare our research findings with others.

\section{Literature review}

\subsection{Tourism}

Since ancient times in human history, tourism has been recognized as a hobby, an active resting activity of man. Today tourism has become a popular socio-economic phenomenon and an indispensable need in social life. The term tourism has become quite popular, it originates from the Greek language meaning to go around. Tourism is associated with leisure and recreation, but due to different circumstances, times and regions, under different research perspectives, the concept of tourism is not the same. In 1963, with the purpose of internationalization, the United Nations Conference on Tourism was held in Rome, experts gave a definition of tourism: "Tourism is a combination of relationships, phenomena and economic activities stemming from individual or collective journeys and stays outside of their usual place of residence or outside their country for peaceful purposes. The place they come to reside is not their workplace".

\subsection{Corporate social responsibility in tourism and hospitality}

The nature of the social responsibility of a tourism business and the hotel is also the social responsibility of a business. In other words, the social responsibility of tourism businesses and hotels is the harmonious combination between the implementation of the provisions of labor law, environmental protection, consumer protection with requirements. of partners, customers, between the interests of tourism businesses and hotels with the benefits of society, between the interests of workers and employers, etc. meet these requirements well. The domestic and international competitiveness of tourism and hotel businesses will increase.

Responsibility for employees: In the tourism and hotel business, the human factor plays a decisive role in creating products and service quality in the tourism and hospitality industry. In fact, each individual employee of the tourism and hotel businesses, regardless of their position and at any time, is always influenced by internal and external impacts from businesses. It is called the "forces" and "forces" for employees, the combination of these forces leads employees to want to work long-term with tourism businesses and hotels or ready to leave. Leaving these organizations to come to other businesses with higher expectations of income or other benefits, or temporarily accepting working for travel and hotel businesses waiting for the opportunity to leave. Thus, the attraction from tourism and hotel businesses is aggregated from factors such as salaries and non-salary incomes, promotion opportunities, job positions, job pressure, opportunities, communication and expansion of relations, status in society, corporate treatment, social insurance and labor safety, etc. Thrust from tourism businesses and 
hotels is combined with factors such as: unsuitable wages, unfair compensation and ineffective stimulating workers, pressure from current jobs, etc. The external attraction is synthesized from the following factors: promotion opportunities, promising salary, favorable working position, social behavior and working environment. Under normal conditions, the stability and balance of the combination of these forces will result in reassuring workers and stable work in tourism and hotel businesses with their position and income. When the attraction of these organizations wins the push from the business and the attraction from outside, the workers will stay to work for tourism and hotel businesses. The more attractive the organizations, the better the workers are at the hotel. On the contrary, the less the difference, the more difficult it is to keep employees in the enterprise. In order to balance the forces affecting workers, tourism and hotel businesses need to recognize that it is a combination of many impact factors such as income, working environment, remuneration, promotion opportunities, ways of communication and conduct of individuals, leadership for employees, etc. Recognizing the importance as well as great benefits, in tourism business and guest hotels should perform well their responsibilities to workers. This responsibility is manifested in many aspects such as lawfully using labor, ensuring good working conditions, ensuring labor safety and hygiene, and paying fair and fair wages. Taking care of employees both physically and mentally through salary, bonus, benefits and adequate insurance, creating a healthy and fit working environment, responsible for developing training for employees, ensuring occupational safety and health and not abusing child labor, respecting the equal rights of men and women based on equity of each person's capacity in recruitment, payment and promotion opportunities; no discrimination in terms of ethnicity, with people with disabilities, with the employees' past.

Environmental Responsibility: In the tourism and hotel business process, tourism businesses and hotels have impacted on the nature and discharged into the nature many types of waste. Waste from tourism and hotel businesses is the type of waste from the production and service provision in tourism and hotel such as plastic bottles, plastic bags, domestic waste, etc. There are many types Waste which must be treated not to affect and threaten the living environment and human health. The social responsibility for the environment of tourism and hotel businesses is to ensure that their operations are eco-friendly, providing good quality, non-harming products, harmful to the health of tourists and guests staying at the hotel.

Responsibility to the community: Responsibility to the community in general, in addition to protecting the environment, charity work is also one of the activities businesses. Tourism and hotel businesses can devote a significant portion of their profits to community assistance activities, employing local residents, creating jobs for them.

Responsibility for customers: In tourism and hotel business, carrying out customer responsibilities means that tourism and hotel businesses must ensure benefits and safety for customers. This means that tourism businesses and hotels that provide accurate, truthful information about the products of tours, hotel services, must be committed to provide customers with products that have high quality, standards and regulations, the quality must be commensurate with the price of the product, without harming the health and lives of customers. Compliance with the Law on "Protection of consumer interests", minimizing civil disputes arising from customers which not only represents the responsibility of tourism and hotel businesses, but also includes important element. In order to build and develop a brand, a resource is becoming increasingly "expensive" with tourism and hotel businesses in the current competitive conditions.

In addition to the above factors, tourism businesses and hotels must also perform well with partners, suppliers, shareholders and fulfill obligations to the State through tax contributions. as well as enforcing legal responsibilities.

\subsection{Financial performance}

Financial performance is the dependent variable used in this study. Financial performance is the financial health of the enterprise, good financial performance proves good solvency of the business. In order to measure financial performance, many studies have mentioned this issue. All studies provide financial performance indicators such as return on equity (ROE), return on assets (ROA), sales profits (ROS) (McWilliams \& Siegel, 2000; Liu et al., 2009; Lee et al., 2016; Servaes \& Tamayo, 2013). In addition, the index shows the market value of tourism businesses and hotels as the market value of equity compared to the book value of equity unlike ROA, ROE, ROS, etc. based on the value of accounting methods only, the book showing the market value reflects the market value of these businesses. In addition to measuring market value, we also use the stock return index (RET), the stock profit is measured by (Stock price difference + Dividend) divided by stock price at the beginning of the yearly finance (Nelling \& Webb, 2009).

\subsection{The impact of corporate social responsibility on financial performance}

According to shareholder theory, the owners when operating business intend to make profit. Therefore, they will act on how to achieve maximum profits for shareholders regardless of other factors. However, in recent decades, researchers have proved that point of view is incomplete and does not guarantee sustainable business development. For that reason, in 1984 Freeman introduced the theory of stakeholders, the theory of stakeholders that businesses can benefit from the implementation of corporate social responsibility with stakeholders of businesses such as employees, community, environment, investors, suppliers and customers, etc. From this awareness, businesses have increasingly improved their business ethically and responsibly more responsible and have left the mark in the hearts of customers, making customers more satisfied and loyal to the business as 
well as improving the image and reputation of the business (Servaes \& Tamayo, 2013; McWilliams and Siegel, 2001). Implementing CSR will help businesses reduce recruitment and training costs while increasing employee motivation and productivity, thereby increasing financial efficiency (Backhaus et al., 2002). Simultaneous implementation of CSR helps to reduce the cost of equity by reducing market failures but informing asymmetry between shareholders and managers (El Ghoul et al., 2011). At the same time, by implementing CSR, businesses have the ability to increase access to capital as well as reduce loan costs (Goss \& Roberts, 2011). We propose the hypothesis that:

$\mathrm{H}_{1}$ : Corporate social responsibility positively affects the financial performance of tourism and hotel businesses in Vietnam.

\subsection{The mediate role of customer satisfaction and corporate reputation}

Fulfilling corporate social responsibility makes customers trust and be satisfied with the services provided by tourism and hospitality businesses from which they will be more loyal and come back. At the same time, the word of mouth is positively increased so the reputation of the business is improved (McWilliams \& Siegel, 2001). For large hotels that are mostly service provided to foreign guests and high-income guests, actions to ensure benefits and customer satisfaction are very important. Therefore, implementing CSR will ensure the provided services to ensure quality and safety for customers from which they will be more satisfied. Today, Vietnam's economy has been developing, tourism destinations in Vietnam have welcomed a large number of customers both at home and abroad. Tourism is a limited resource that wants to preserve and promote the advantage of tourism business, forcing tourism businesses to conduct business responsibly and ethically by performing social responsibility. enterprise. Corporate social responsibility helps improve the image and reputation of the business. A good reputation and reputation will help tourism businesses and hotels attract customers, partners, investors and employees, thereby increasing operational efficiency as well as financial efficiency. With the prestigious brand affirmed, charismatic, causing sympathy with partners and consumers; focus on public relations and well fulfill social obligations; along with guaranteed service quality, competitive prices will help tourism and hotel businesses have more opportunities to reach international markets, expand market share and maintain market share growth. The core processes in the tourism and hotel businesses are the basic processes, the secret of success in the production and business of tours, catering services, accommodation, etc. so the performance of these processes are related to the survival of the hotel. From good implementation, human capacity, process management and increased supply capacity will ensure core process performance and improve financial efficiency for these organizations. We propose the hypothesis:

$\mathrm{H}_{2}$ : Reputation and customer satisfaction play a mediate role in the relationship between corporate social responsibility and financial performance in Vietnam's tourism and hospitality.

\subsection{The moderate role of foreign ownership and size}

The percentage of foreign ownership is regarded as a variable that regulates corporate social responsibility in emerging countries and developing economies. Foreign shareholders, usually investors from developed countries, and they are more interested in implementing corporate social responsibility than domestic shareholders. Because they often focus on sustainable development for businesses rather than hot development in the short term. In addition, foreign shareholders often have little direct involvement in the operation of the company. For an emerging country, where a developing economy, with an incomplete system of laws and institutions, ensuring the symmetry of information is extremely important. Investing in corporate social responsibility can reduce information asymmetry for businesses (Orlitzk et al., 2003). Empirical studies have demonstrated that foreign ownership has a positive impact on corporate social responsibility performance (Orlitzk et al., 2003; Hillman \& Keim, 2001). In addition, there are several studies suggesting that foreign ownership also has a positive impact on the financial performance of firms (Doukas \& McKnight, 2005; Chen et al., 2009). Foreign investors, often with a higher expectation in the organization, are more than just operational efficiency, which is a sustainable development orientation. In addition, the greater the tourism and hospitality businesses, the greater the implementation of social responsibility because that is the corporate culture is the long-term development strategy of these organizations. On the contrary, the smaller the business, the greater the amount of money spent on social responsibility is the difficulty that these businesses are living with the corporate social responsibility costs reduction. Aras et al. (2010) demonstrated that firm size had a positive impact on corporate social performance, while firm size also has a positive impact on financial performance. Therefore, we propose the following hypothesis:

$\mathrm{H}_{3}$ : Foreign ownership and firm size play a moderate role in the relationship between corporate social responsibility and financial performance in Vietnam's tourism and hospitality.

\section{Research method}

\subsection{Research sample}

Travel products are also a very specific product compared to other products. It is a combination of two or more services (car, hotel ...) of different partners to create a product package - package tour. At the same time, the tourism product is intangible, customers cannot see or preview it, they can only feel the quality of a tourist vacation after buying a tour. Travel products are 
not as inventory-oriented as other goods, so tourism businesses (hotels) often try to sell their products at lower prices at the last minute. Vietnam is a special country with an incomplete political and legal environment. Vietnam is transitioning from a centrally planned economy to a market economy with the regulation of a single Party. The socialist-oriented market economy makes the Vietnamese economy unique compared to other countries in the world. In addition, Vietnamese culture is a longstanding wet rice culture influenced by Confucian culture similar to that of China, Korea and other Asian countries. Culture has a positive influence on the attitude of stakeholders such as investors, customers, etc. The study was conducted on 886 tourism and hotel businesses in Vietnam. We conducted direct and email surveys to over 1,000 travel and hotel businesses in Vietnam over a period of 6 months. After that we collected 956 questionnaires. In the process of cleaning the data to include in the analysis, only 886 questionnaires representing 886 tourism and hospitality businesses were satisfied to analyze the impact of corporate social responsibility. Financial efficiency of tourism businesses and hotels in Vietnam.

\subsection{Research models}

Fig.1 demonstrates the proposed study of this paper.

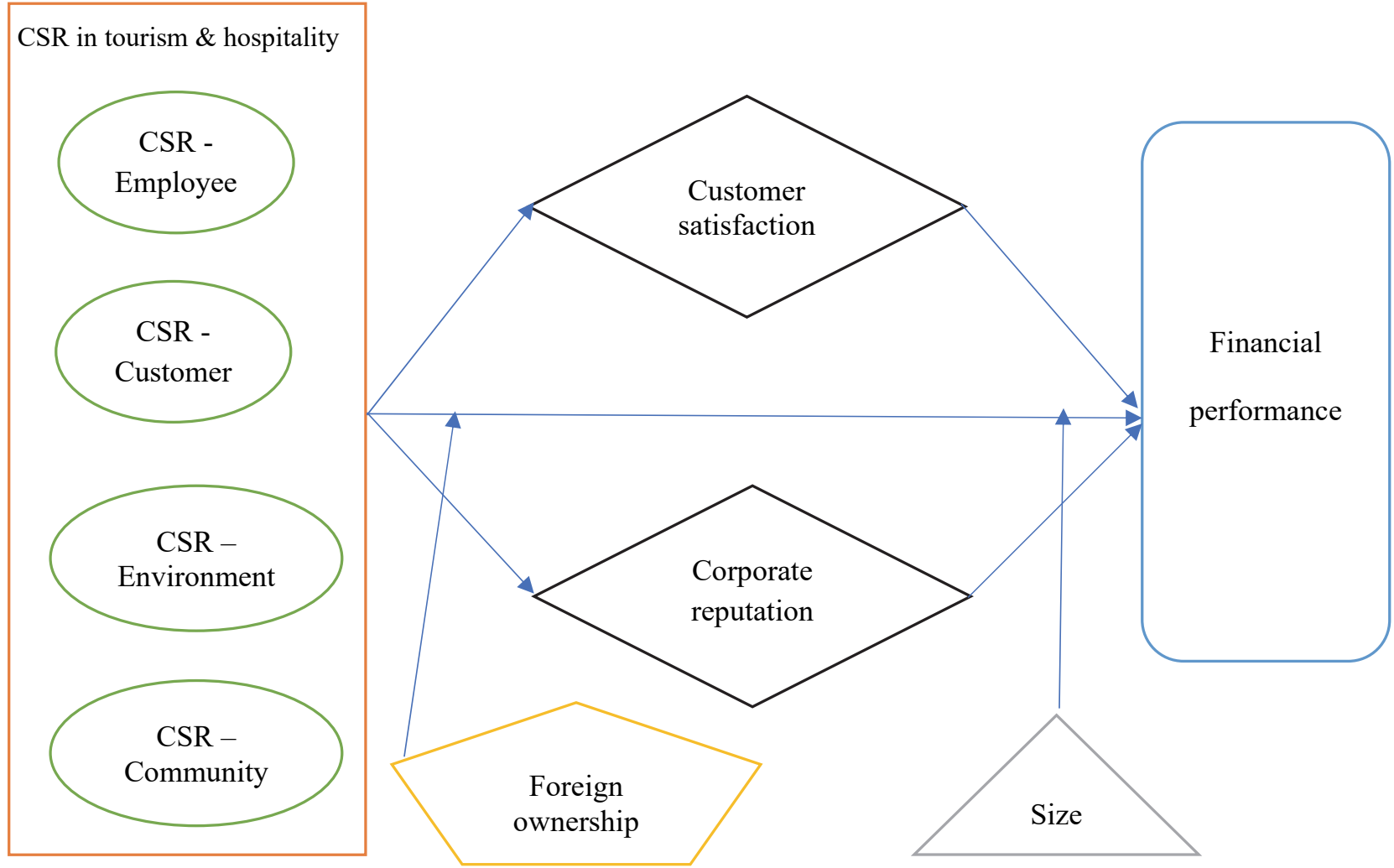

Fig.1. Research model

The corporate social responsibility of tourism and hospitality businesses is measured from Le et al. (2019); Manner (2010); Phan \& Nguyen (2018) and Tran et al. (2019) and it includes 29 indicators measured on a scale of 1 to 5 Likert with corresponding levels from totally disagree to strongly agree. Financial performance is measured through three dimensions: profitability, growth and market value of tourism and hotel businesses in Vietnam. The financial performance indicators developed from the research of Santos and Bristo (2012) were measured against the average expectations for the last three years i.e. 2016, 2017 and 2018. Indicators compared on a Likert scale 5 levels from 1 is much lower to 5 is much higher. Customer satisfaction is measured through 5 items developed from research by Le et al. (2019); Porter \& Kramer, (2006) and Saeidi et al. (2015) measured using a 5-point Likert scale where one represents completely disagree and 5 denotes strongly agree. Corporate reputation is developed from the research of Roxas \& Coetzer (2012) and Saidie et al. (2015) which is measured through 5 items rated by a 5-point Likert scale from 1 for strongly disagree and 5 for totally agree.

\subsection{Analytical techniques}

We use Excel software (2016) to import data from the questionnaire, then the data is analyzed by reliability using SPSS 22 software, then we remove the inappropriate scale, no satisfied to include Smart PLS 3.0 software for data analysis. PLS-SEM is designed and developed to alleviate the pressure due to large sample sizes and the strict requirements of relationships in the CB-SEM model (Hair et al., 2017; Henseler, 2009). With only fewer observations collected, PLS-SEM can identify highly complex models with high reliability. Therefore, PLS-SEM is the second generation of analysis with more accurate results (Hair et al., 2017; Chin, 1998). The analysis steps are as follows: 
Step 1: Analyze reliability by Cronbach's Alpha coefficient and total correlation coefficient: With Cronbach's Alpha coefficient> 0.6, the reliability of the scale is reasonable. Corrected Item-Total Correlation: indicates whether or not the current variable contributes to the overall scale; The condition must be> 0.3 (Nguyen Dinh Tho, 2009).

Step 2: Evaluate structural models:

Evaluation of general reliability and discriminant Validity: To test this, the correlation coefficients between component concepts of a concept must be $<0.9$ to achieve discriminant value. Assessing the appropriateness of the research model, evaluating $\mathrm{R}$ - square, $\mathrm{f}$ - square values.

Step 3: Test the research hypotheses:

Using PLS and Bootstrap analysis techniques to test the research hypotheses with hypotheses $<5 \%$ significance level is accepted.

\section{Research results}

The reliability test of the scale on SPSS 22 software shows that out of 29 items measuring the aspects of corporate social responsibility, 3 items have a Cronbach Alpha coefficient $<0.6$ and a correlation of the total variable $<0.3$ so we have removed 3 items CSR-Employee 1; CSR - Community 4 and CSR - Environment 7. After three scales have been removed, all scales meet the analytical conditions and are included in the next analysis. The results of evaluating the general reliability of the latent variables and the scales are summarized in Table 1 as follows:

Table 1

The results of reliability of the latent variables and validity

\begin{tabular}{lcccc} 
& Cronbach's Alpha & rho_A & Composite Reliability & Average Variance Extracted (AVE) \\
\hline CSR in tourism and hospitality & 0.981 & 0.981 & 0.981 & 0.898 \\
CSR-Community & 0.898 & 0.898 & 0.911 & 0.638 \\
CSR-Customer & 0.911 & 0.911 & 0.910 & 0.672 \\
CSR-Employee & 0.910 & 0.911 & 0.872 & 0.629 \\
CSR-Environment & 0.872 & 0.872 & 0.920 & 0.694 \\
Corporate reputation & 0.920 & 0.920 & 0.838 & 0.697 \\
Customer satisfy & 0.838 & 0.841 & 0.948 & 0.634 \\
Financial performance & 0.949 & 0.952 & & 0.650 \\
\hline
\end{tabular}

From the results in Table 1, all scales are satisfied for the next analytical condition. According to Hair et al. (2014), Cronbach's Alpha coefficient $>0.7$ is guaranteed and AVE coefficient $>0.5$. Therefore, all scales meet the conditions. Next, we evaluate the discrimination of the scales. The analytical results are as follows:

Table 2

Discriminant Validity (Fornell-Larcker Criterion)

\begin{tabular}{|c|c|c|c|c|c|c|c|c|}
\hline & $\begin{array}{c}\text { CSR in tourism and } \\
\text { hospitality }\end{array}$ & $\begin{array}{l}\text { CSR-Com- } \\
\text { munity }\end{array}$ & $\begin{array}{c}\text { CSR- } \\
\text { Customer } \\
\end{array}$ & $\begin{array}{l}\text { CSR-Em- } \\
\text { ployee }\end{array}$ & $\begin{array}{l}\text { CSR-Envi- } \\
\text { ronment }\end{array}$ & $\begin{array}{l}\text { Corporate } \\
\text { reputation }\end{array}$ & $\begin{array}{c}\text { Customer } \\
\text { satisfy }\end{array}$ & $\begin{array}{l}\text { Financial per- } \\
\text { formance }\end{array}$ \\
\hline $\begin{array}{l}\text { CSR in tourism and } \\
\text { hospitality }\end{array}$ & 0.818 & & & & & & & \\
\hline CSR-Community & 0.038 & 0.799 & & & & & & \\
\hline CSR-Customer & 0.012 & 0.010 & 0.820 & & & & & \\
\hline CSR-Employee & 0.041 & 0.049 & 0.020 & 0.793 & & & & \\
\hline CSR-Environment & 0.017 & 0.022 & 0.267 & 0.037 & 0.833 & & & \\
\hline $\begin{array}{l}\text { Corporate } \\
\text { reputation }\end{array}$ & 0.457 & 0.470 & 0.450 & 0.474 & 0.430 & 0.835 & & \\
\hline Customer satisfy & 0.211 & 0.240 & 0.185 & 0.197 & 0.221 & 0.221 & 0.796 & \\
\hline $\begin{array}{c}\text { Financial } \\
\text { performance }\end{array}$ & 0.400 & 0.432 & 0.394 & 0.394 & 0.391 & 0.214 & 0.281 & 0.806 \\
\hline
\end{tabular}

The analysis results in Table 2 show that all potential variables satisfy the discrimination. The diagonal coefficients are larger than the rest. The result of evaluating $\mathrm{R}^{2}$ value is as follows:

Table 3

R square

\begin{tabular}{lcc}
\hline & R Square & R Square Adjusted \\
\hline Corporate reputation & 0.269 & 0.267 \\
Customer satisfy & 0.244 & 0.242 \\
Financial performance & 0.321 & 0.316 \\
\hline
\end{tabular}


The above results show that the underlying variables in the model explain $32.1 \%$ of the variation in financial efficiency. The aspects of corporate social responsibility explain $26.9 \%$ of the variability of the tourism and hotel business reputation, and the aspects of corporate social responsibility explain $24.4 \%$ of the variation in tourism and hotel businesses.

The result of evaluating $\mathrm{F}^{2}$ value is as follows:

Table 4

F Square

\begin{tabular}{|c|c|c|c|c|c|c|c|c|}
\hline & 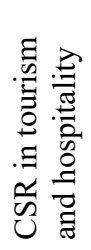 & 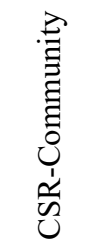 & 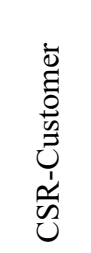 & 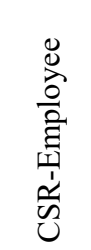 & 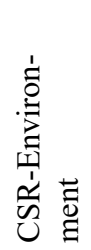 & 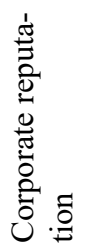 & 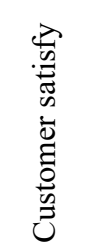 & 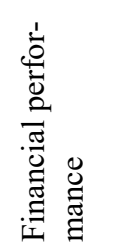 \\
\hline CSR in tourism and hospitality & & 0.213 & 0.211 & 0.208 & 0.264 & 0.243 & 0.256 & 0.201 \\
\hline \multicolumn{9}{|l|}{ CSR-Community } \\
\hline \multicolumn{9}{|l|}{ CSR-Customer } \\
\hline \multicolumn{9}{|l|}{ CSR-Employee } \\
\hline \multicolumn{9}{|l|}{ CSR-Environment } \\
\hline Corporate reputation & & & & & & & & 0.178 \\
\hline Customer satisfy & & & & & & & & 0.182 \\
\hline Financial performance & & & & & & & & \\
\hline
\end{tabular}

From the results in Table 4, the values of $\mathrm{f}$ square meet the analytical conditions. After the scales have met the initial analysis conditions, we conduct tests of research hypotheses based on the research model built. Bootstrap's results from the testing model of research hypotheses are as follows:

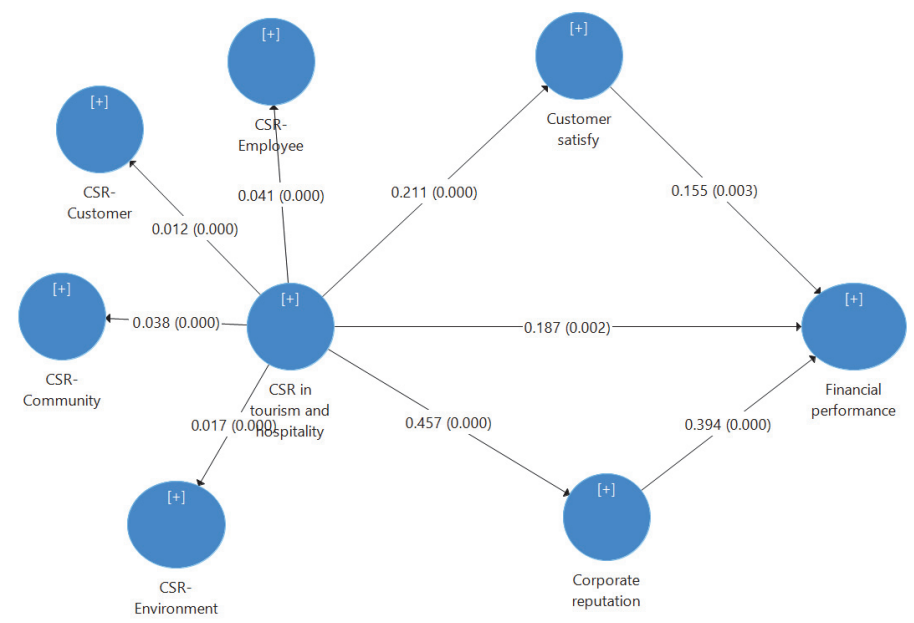

Fig. 2. Hypothesis test results (Bootstrap out)

From the results in Fig. 2, CSR implementation in tourism and hospitality businesses has positive benefits such as improving customer satisfaction, improving the image and reputation of the business and thereby improve the financial performance of these businesses. Specifically, the implementation of CSR in tourism and hotel businesses increases customer satisfaction with a fairly large impact factor of 0.211 at the $1 \%$ significance level $(\mathrm{P}$-value $=0.000)$, which means that the more CSR is performed, the more satisfied guests and hotel guests will stay. In addition, the implementation of CSR in tourism and hotel businesses has greatly increased the reputation of the business with a very high impact coefficient of 0.457 at $1 \%$ significance level ( $\mathrm{P}$-value $=0.000)$. Since then, encouraging tourism businesses and hotels in particular and businesses in general should implement CSR to improve the reputation to enhance the business image in the hearts of customers and society. In addition, the implementation of CSR still has a direct impact on the financial performance of tourism and hotel businesses with a positive impact coefficient of 0.187 at an average with a $1 \%$ significance level $(\mathrm{P}$ - value $=0.002)$, which means that in the customer satisfaction model and business reputation, there is no full mediate role, so CSR still has a direct impact on statistical significance financial performance in these businesses. Customer satisfaction positively impacts on financial performance with an impact coefficient of 0.155 at the $1 \%$ significance level $(\mathrm{P}-\mathrm{value}=0.003)$. Finally, corporate reputation has a strong 
impact on financial performance with an impact coefficient of 0.394 at the $1 \%$ significance level $(\mathrm{P}-\mathrm{value}=0.000)$. Indeed, a good corporate reputation will improve financial performance both in terms of value in money through franchising or through non-monetary aspects such as attracting customers, attracting employees. From there, improve the financial performance for the business.

Summarize the hypothesis test results as follows:

Table 5

Path Coefficients (Mean, STDEV, T-Values, P-Values)

\begin{tabular}{|c|c|c|c|c|c|}
\hline & $\begin{array}{l}\text { Original Sample } \\
(\mathrm{O})\end{array}$ & $\begin{array}{c}\text { Sample } \\
\text { Mean (M) }\end{array}$ & $\begin{array}{c}\text { Standard Deviation } \\
\text { (STDEV) }\end{array}$ & $\begin{array}{c}\text { T Statistics } \\
(|\mathrm{O} / \mathrm{STDEV}|)\end{array}$ & P Values \\
\hline CSR in tourism and hospitality $\rightarrow$ CSR-Community & 0.038 & 0.037 & 0.008 & 133.816 & 0.000 \\
\hline CSR in tourism and hospitality $\rightarrow$ CSR-Customer & 0.012 & 0.013 & 0.017 & 58.398 & 0.000 \\
\hline CSR in tourism and hospitality $\rightarrow$ CSR-Employee & 0.041 & 0.041 & 0.008 & 135.673 & 0.000 \\
\hline CSR in tourism and hospitality $\rightarrow$ CSR-Environment & 0.017 & 0.017 & 0.012 & 87.177 & 0.000 \\
\hline CSR in tourism and hospitality $\rightarrow$ Corporate reputation & 0.457 & 0.459 & 0.041 & 11.023 & 0.000 \\
\hline CSR in tourism and hospitality $\rightarrow$ Customer satisfy & 0.211 & 0.210 & 0.054 & 3.895 & 0.000 \\
\hline CSR in tourism and hospitality $\rightarrow$ Financial performance & 0.187 & 0.186 & 0.061 & 3.055 & 0.002 \\
\hline Corporate reputation $\rightarrow$ Financial performance & 0.394 & 0.401 & 0.059 & 6.638 & 0.000 \\
\hline Customer satisfy $\rightarrow$ Financial performance & 0.155 & 0.156 & 0.051 & 3.018 & 0.003 \\
\hline
\end{tabular}

The results show that all the hypotheses are statistically significant, meaning that implementing corporate social responsibility improves the financial performance of Vietnam's tourism and hospitality businesses. Next, we expect that large or foreignowned tourism and hotel businesses will perform better social responsibility and impact financial performance even more. To do that, we conduct an examination of the regulatory role of foreign ownership and firm size. The testing results are as follows:

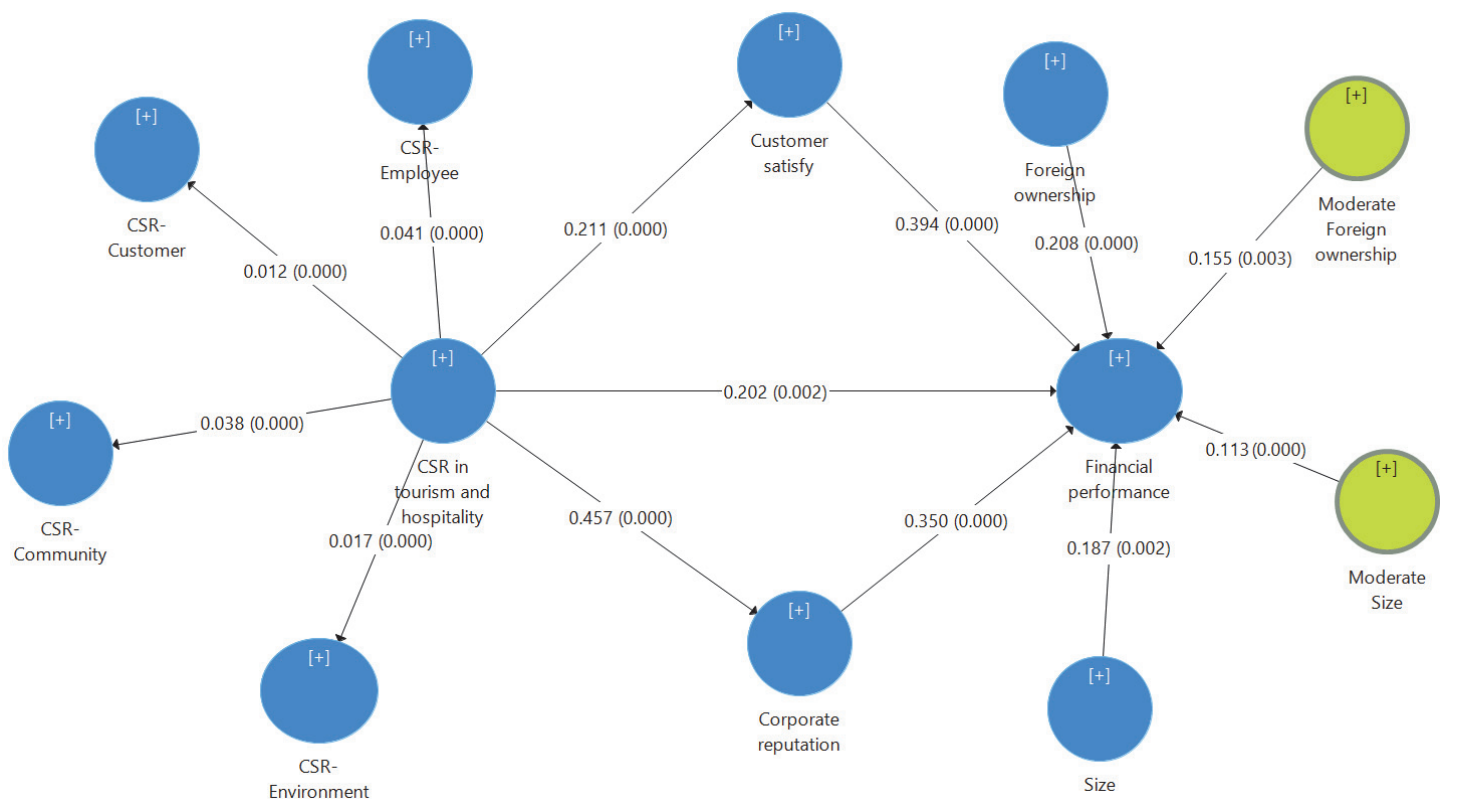

Fig. 3. Results of the moderator role test (Bootstrap out)

The results in Fig. 3 show that Foreign ownership and Size both play a role in regulating the relationship between corporate social responsibility in tourism and hotel businesses to the financial performance of these organizations. Foreign ownership has a moderate regulatory impact with an impact factor of 0.155 at $1 \%$ significance level (P-value $=0.003$ ), and the size of the business also has a moderate regulatory role. smaller than foreign ownership at the impact level of 0.113 at the $1 \%$ significance level $(\mathrm{P}$-value $=0.000)$. Next, we visualize the regulatory role of foreign ownership and firm size as follows:

The analysis of the regulatory role of foreign ownership is in Fig. 4. 


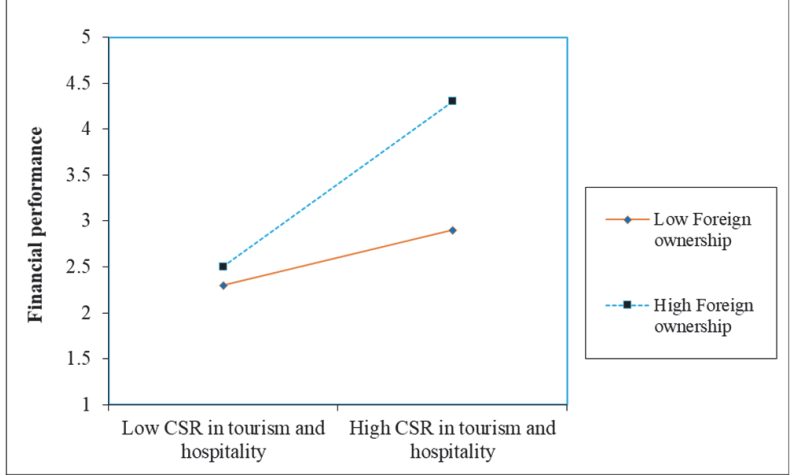

Fig. 4. Moderate role of Foreign ownership

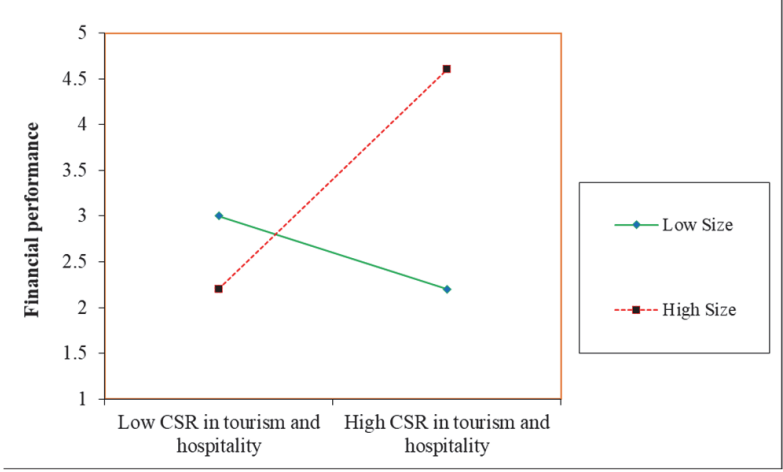

Fig. 5. Moderate role of Size

With more foreign-owned tourism and hotel enterprises, the implementation of CSR increases the financial efficiency very strongly, which is understandable because tourism and hotel enterprises are very concerned about their responsible conduct and ethical business practices. Therefore, the implementation of CSR makes them more satisfied and confident, which increases revenue, increases image and reputation for businesses and ultimately improves financial efficiency. In contrast, the fewer foreign owned businesses are, the more effective CSR is to improve their financial performance, but to a lesser extent since the customers they serve are interested in many other aspects. Next, we analyze the regulatory role of firm size in Fig. 5. From the results of the analysis in Fig. 5 we understand that the greater the tourism businesses and hotels perform the more CSR makes the financial efficiency. On the contrary, the smaller the tourism and hotel businesses, the worse CSR implementation. This means that, for larger tourism and hotel businesses, CSR implementation will bring good operational and financial efficiency, but for small tourism and hotel businesses, there is a more negative effect for the implementation of CSR, since small businesses do not have a long-term development strategy so they live on the same CSR costs that they cut during the operation. Therefore, these businesses need a long-term action strategy to ensure sustainable development.

\section{Conclusion}

Deploying well corporate social responsibility in tourism businesses and hotels in particular and Vietnamese businesses in general will not only help businesses do well, but also support businesses to solve strategic issues associated with businessrelated strategies and social issues. Corporate social responsibility is not just to make businesses feel content, not just ordinary promotional, charitable or small sponsorship activities that require continuity, long-term commitment to the interests of businesses and to the benefits of society. Corporate social responsibility should be seen as the benefit of businesses so that they can actively deploy towards an effective business community with branded products trusted by consumers, building internal human resources, valuable resources, position and good reputation in society. Therefore, improving the corporate social responsibility of tourism and hotel businesses is very important, ensuring the sustainable development of businesses and the country's economy. To do this, we propose the following major solutions:

Firstly, propagandizing and raising awareness of social responsibility of enterprises headed by leaders and managers of enterprises in production and environmental protection. This is a necessary job, in order to have the right behavior in protecting and resolving environmental issues. The implementation of social responsibility should be considered as an ethical act and controlled by an ethical motive.

Secondly, constantly improving, amending and supplementing regulations and sanctions on environmental protection, resolutely strictly handling violations of the law on environmental protection. The Law on Environmental Protection plays an important role in controlling the behavior of businesses in relation to the natural environment. Completing the system of legal documents on environment and environmental protection is an important legal basis for improving the social responsibility of enterprises in environmental protection. Thirdly, it is necessary to strengthen the environmental protection work, to strengthen the state management capacity on environmental protection for localities, including the training of professional management officials, complete the environmental management system, etc.

\section{References}

Aras, G., Aybars, A., \& Kutlu, O. (2010). Managing corporate performance. International Journal of productivity and Performance management, 59, 229-254.

Backhaus, K. B., Stone, B. A., \& Heiner, K. (2002). Exploringthe relationship between corporate social performance and employer attractiveness. Business \& Society, 41(3), 292-318.

El Ghoul, S., Guedhami, O., Kwok, C. C., \& Mishra, D. R. (2011). Does corporate social responsibility affect the cost of capital?. Journal of Banking \& Finance, 35(9), 2388-2406.

Goss, A., \& Roberts, G. S. (2011). The impact of corporate social responsibility on the cost of bank loans. Journal of Banking \& Finance, 35(7), 1794-1810. 
Hair, Jr., J.F., Matthews, L.M., Matthews, R.L. \& Sarstedt, M. (2017). PLS-SEM or CB-SEM: updated guidelines on which method to use. International Journal of Multivariate Data Analysis, 1(2). 236- 268. DOI: 10.1504/IJMDA.2017.087624

Hair, J.F., Hult, G.T.M., Ringle, C.M. \& Sarstedt, M. (2014). A Primer on Partial Least Squares Structural Equation Modeling, Sage, Thousand Oaks, CA.

Hasan, I., Kobeissi, N., \& Wang, H. (2018). Corporate social responsibility and firm financial performance: The mediating role of productivity. Journal of Business Ethics, 149, 671 - 688.

Henseler, J., Ringle, C. M., \& Sinkovics, R. R. (2009). The use of partial least squares path modeling in international marketing. In New challenges to international marketing. Emerald Group Publishing Limited.

Hillman, A. J., \& Keim, G. D. (2001). Shareholder value, stakeholder management, and social issues: What's the bottom line?. Strategic management journal, 22(2), 125-139.

Le, T., Nguyen, T., Phan, T., Tran, M., Phung, X., Tran, T., \& Giao, K. (2019). Impact of corporate social responsibility on supply chain management and financial performance in Vietnamese garment and textile firms. Uncertain Supply Chain Management, 7(4), 679-690.

Lee, S., \& Jung, H. (2016). The effects of corporate social responsibility on profitability. Management Decision, 54(6), 13831406. doi:10.1108/MD-07-2015-0268

Liu, Y., \& Zhou, X. (2009). Corporate social responsibility and customer loyalty: A conceptual framework. IEEE Xplore Digital Library, 978(1), 794-794.

Manner M. H. (2010), The impact of CEO characteristics on corporate social performance. Journal of Business Ethics, 93, 53-72. DOI 10.1007/s10551-010-0626-7.

McWilliams, A. \& Siegel., D. . (2000). Corporate social responsibility and financial performance: correlation or misspecification? Strategic Management Journal, 21(5), 603-609.

McWilliams, A., \& Siegel, D. (2001). Corporate social responsibility: A theory of the firm perspective. Academy of Management Review, 26(1), 117-127.

Mishra, S., \& Suar, D. (2010). Does corporate social responsibility influence firm performance of Indian companies?. Journal of Business Ethics, 95(4), 571-601.

Nelling, E., \& Webb, E. (2009). Corporate social responsibility and financial performance: the "virtuous circle" revisited. Review of Quantitative Finance and Accounting, 32(2), 197-209.

Nguyen, T. D. (2009). Place development: Attributes and business customer satisfaction in Tien Giang Province, Vietnam. Journal of Macromarketing, 29(4), 384-391.

Orlitzky, M., Schmidt, F. L., \& Rynes, S. L. (2003). Corporate social and financial performance: A meta-analysis. Organization Studies, 24(3), 403-441.

Phan, T. T. H., \& Nguyen, T. T. L. (2018). Research on awareness and status of corporate social responsibility in Vietnamese textile enterprises. Journal of Economics and Development, 254(8/2018), 106-112.

Porter, M.E. \& Kramer, M.R. (2006). Strategy and society: The link between competitive advantage and corporate social responsibility. Harvard Business Review, 84(12), 78-92.

Roxas, B., \& Coetzer, A. (2012). Institutional Environment, Managerial Attitudes and Environmental Sustainability Orientation of Small Firms. Journal of Business Ethics, 111(4), 461-476. Retrieved from http://www.jstor.org/stable/23324813

Saeidi, S. P., Sofian, S., Saeidi, P., Saeidi, S. P., \& Saaeidi, S. A. (2015). How does corporate social responsibility contribute to firm financial performance? The mediating role of competitive advantage, reputation, and customer satisfaction. Journal of Business Research, 68(2), 341-350. doi:https://doi.org/10.1016/j.jbusres.2014.06.024

Santos, \& Brito. (2012). Toward a subjective measurement model for firm performance. Brazilian Administration Review, 9 , 95-117.

Servaes, H., \& Tamayo, A. (2013). The impact of corporate social responsibility on firm value: The role of customer awareness. Management Science, 59(5), 1045-1061.

Tran, H., Bui, V., Phan, T., Dau, X., Tran, M., \& Do, D. (2019). The impact of corporate social responsibility and risk management on financial performance: The case of Vietnamese textile firms. Management Science Letters, 9(7), $1029-1036$.

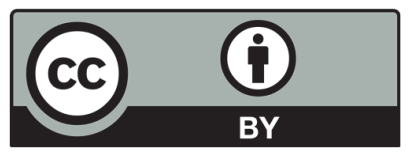

(C) 2020 by the authors; licensee Growing Science, Canada. This is an open access article distributed under the terms and conditions of the Creative Commons Attribution (CC-BY) license (http://creativecommons.org/licenses/by/4.0/). 